УДК 378.147:004

DOI: 10.37026/2520-6427-2020-101-1-85-90

\section{Микола КОзяР,}

доктор педагогічних наук, професор,

завідувач кафедри теоретичної механіки, інженерної графіки та машинознавства

Національного університету водного господарства та природокористування, м. Рівне

\section{Юрій ФЕЩУК,}

кандидат педагогічних наук,

доиент кафедри технологічної освіти

Рівненського державного гуманітарного університету

ОЛЕКсій ПАРФЕНЮК,

старший викладач кафедри теоретичної механіки, інженерної графіки та машинознавства

Начіонального університету водного

господарства та природокористування, м. Рівне

\title{
РОЛЬ РЕГІОНАЛЬНОЇ ОЛІМПІАДИ 3 ГЕОМЕТРИЧНОГО МОДЕЛЮВАННЯ ТА АНІМАЦІЇ ЗБІРОК У ПРОФЕСІЙНОМУ СТАНОВЛЕННІ МАЙБУТНЬОГО ФАХІВЦЯ
}

\begin{abstract}
У статті розкривається досвід організації та проведення регіональної олімпіади з геометричного моделювання та анімації збірок засобами комп'ютерної графіки з метою активізації пізнавальної дiяльності здобувачів вищяої освіти в процесі їх графічної підготовки. Акиентується увага на необхідності володіння майбутніми фахівцями засобами комп'ютерного моделювання, які дозволять індивідуалізувати й органічно поєднати навчання та самонавчання, перетворивши процес теоретичної підготовки в його практичний досвід.
\end{abstract}

Ключові слова: заклади вищої освіти, здобувачі вищої освіти, науково-дослідна робота та ї̈ форми, графічна підготовка, комп'ютерна графіка, засоби тривимірного та чотиривимірного моделювання, регіональна олімпіада, графічна компетентність.

B статье раскрывается опыт организации $u$ проведения региональной олимпиады по геометрическому моделированию и анимации сборок средствами компьютерной графики с ичелью активизаџии познавательной деятельности соискателей высшего образования в проиессе их графической подготовки. Акцентировано внимание на необходимости владения будущими специалистами средствами компьютерного моделирования, которые позволят индивидуализировать $и$ органично совместить обучение $u$ самообучение, превратив прочесс теоретической подготовки в его практический опыт.

Ключевые слова: учреждения высшего образования, соискатели высшего образования, научно-исследовательская работа и ее формы, графическая подготовка, компьютерная графика, средства трехмерного и четырехмерного моделирования, региональная олимпиада, графическая компетентность.

The urgency of the problem of the educational environment for the training of candidates for higher education technical specialties in higher education institutions due to its complexity and dynamism, information saturation and the increasing requirements to the modern specialist. We proceed from the understanding of the educational environment as an integrated system of values, aimed at the realization of the set candidates of higher education the purposes, tasks, the main source of their spiritual and professional development. The search for solutions and the implementation of training of applicants of higher education encourages the analysis of the educational environment as a whole systems phenomenon and its individual components. Given that the educational environment is considered as a zone of interaction between educational systems, the individual elements of educational processes, we focus on research work and its forms, and particularly in the regional subject Olympiad.

We consider regional Olympiad on geometric modeling as a creative competition with theoretical and practical training of applicants for higher education, which is aimed at enhancing their cognitive activities and is an element of research work. Methodological aspects of the event so to combine the Olympics and learning that ensures the optimization of the educational process. We used the following modes of study: individual; group and bell to Lancasters. When the bell lancastershire form of education applicants for higher education who visit the 
club are divided into groups which are attached to the applicant's senior courses (III-IV) - monitor. Monitors have several graphic packages. They passed this knowledge to their colleagues. The result of this approach, applicants for higher education alone has mastered several graphic packages and increased the level of graphical competence.

Key words: institutions of higher education, candidates for higher education, research work and its form, graphic training, computer graphics, tools, three-dimensional and four-dimensional modeling, the graphical competence.

Постановка проблеми. Головним завданням закладів вищої освіти (далі - 3BO) є посилення уваги до підготовки фахівців якісно нового рівня, а саме формування активної творчої особистості, здатної самостійно вирішувати виробничі завдання, пов'язані з реалізацією професійних функцій. Проектуючи та конструюючи технічні нововведення, майбутні фахівці не лише постійно вдосконалюють світ техніки і технологій, а й оптимізують умови виробництва. Неабиякої актуальності при цьому набуває графічна підготовка здобувачів вищої освіти засобами комп'ютерної графіки.

Аналіз наукових досліджень і публікацій. Практичні аспекти графічної підготовки майбутніх фахівців у ЗВО засобами комп'ютерної графіки висвітлено в працях вітчизняних та зарубіжних науковців, зокрема В. Бойка, О. Джеджули, М. Козяра, I. Нищака, Г. Райковської, М. Романкова, В. Рукавішнікова, О. Ожга, Н. Федотової, М. Хапіліна, О. Хейфеца, Г. Хубетдінова, Т. Чемоданової, Є. Шангіна, Л. Шкіци, М. Юсупової та ін. Більшість учених вказують на необхідність удосконалення навчальних програм підготовки здобувачів вищої освіти різних технічних спеціальностей 3 урахуванням освітніх і наукових потреб, що знаходить своє відображення насамперед у навчальних планах, формах та методах роботи ЗВО. При цьому В. Бойко [1] зауважує, що сучасна інженерно-графічна підготовка засобами комп'ютерного моделювання ставить нові завдання у викладанні графічних дисциплін в умовах сьогодення. До цих завдань відноситься не лише засвоєння теоретичних знань з інженерно-графічних дисциплін та їх практичне використання, а й володіння графічними комп'ютерними програмами. Натомість М. Ожга зазначає, що, «незважаючи на значну кількість досліджень, проблеми навчання систем тривимірного комп'ютерного проектування, побудови на його основі реалістичного зображення або анімованого відеокліпа залишаються недостатньо розглянутими» $[6$, с. 7]. Науковець пропонує методику навчання систем 3D проектування майбутніх фахівців. Тому вдосконалення їх графічної освіти в умовах інформатизації має грунтуватися на дидактичному та функціональному потенціалі інтелектуальних комп'ютерних систем автоматизованого проектування. Поряд з цим, на нашу думку, важливу роль у формуванні творчого потенціалу здобувачів вищої освіти відіграє їх участь в організованій і систематичній науково-дослідній роботі. Завдання означеної роботи полягає в розвитку пошукової, дослідницької діяльності, творчому розв'язанні завдань, а також у формуванні вмінь щодо застосування методів наукових досліджень на практиці для посилення графічної компетентності.

ЗВО активно використовують такі форми науково-дослідної роботи здобувачів вищої освіти, як: участь у предметних олімпіадах, конкурсах, семінарах, конференціях; виконання науково-дослідних та кваліфікаційних (дипломних) робіт; робота в науково-дослідних лабораторіях, наукових i творчих гуртках тощо. Аналіз науково-методичних праць [3-5; 7-13] iз різноманітних аспектів досліджуваної проблеми свідчить про неабияку їі важливість. Більшість науковців зупиняються на дослідженні ролі предметних олімпіад. Предметна олімпіада у ЗВО - це вид інтелектуального змагання між здобувачами вищої освіти, яке допомагає розвинути дух суперництва, урізноманітнити навчальний процес тощо. Під час таких олімпіад здобувачі вищої освіти мають продемонструвати вміння творчо застосовувати отримані теоретичні знання для вирішення конкретних завдань, проявити ініціативу у виборі оптимальних шляхів i методів їх виконання. Олімпіада як форма організації наукової роботи добре сприймається здобувачами вищої освіти, зокрема й молодших курсів.

Мета статті - розкрити окремі аспекти та форми науково-дослідної роботи здобувачів вищої освіти в умовах закладу вищої освіти; продемонструвати роль та місце регіональної олімпіади з комп'ютерного моделювання засобами тривимірної та чотиривимірної графіки як важливого компонента освітнього середовища ЗВО у формуванні готовності здобувачів вищої освіти до професійної діяльності.

Виклад основного матеріалу. 3 урахуванням реалій сучасного виробництва у графічній підготовці фахівців виникла об'єктивна необхідність розробки нових педагогічних технологій, що забезпечують орієнтацію на інноваційну діяльність, усвідомлену постановку нових творчих завдань і здатність вирішувати ці завдання сучасними професійними методами. На сучасному етапі сфери машинобудування, виробництва і транспорту висувають до здобувачів вищої освіти високі вимоги щодо професійної підготовки водночас із вимогами ринку до швидкої адаптації на робочому місці, виконання поставлених виробничих завдань i подальшого саморозвитку та підвищення своїх професійних навичок. Це насамперед покладає на ЗВО, які здійснюють підготовку майбутніх технічних фахівців, завдання з пошуку нових та оптимізації вже існуючих методів навчання в процесі їх підготовки.

Одним із таких напрямів є залучення талановитої та обдарованої молоді до участі в конкурсах, олімпіадах, які передусім спрямовані на розвиток творчого потенціалу здобувачів вищої освіти. Групова форма навчання значно більшою мірою аніж фронтальна та індивідуальна моделює виробничу діяльність технічного фахівця. За таких умов, що особливо актуально для молодших курсів, виявляються особистості, що володіють «нешаблонним» підходом до вирішення технічних завдань і мають потенціал у проектуванні та конструюванні технічних об'єктів.

Важливим і затребуваним сучасним виробництвом є розвиток у здобувачів вищої освіти навичок діяти ефективно у стресових ситуаціях та приймати водночас оригінальні й нестандартні рішення. Найбільш ефективною формою при цьому є регіональні предметні олімпіади, які, попри все інше, сприяють підвищенню інтересу та затребуваності навчальних дисциплін, зокрема й графічних.

Ураховуючи вищезазначене, регіональну олімпіаду з геометричного моделювання ми розглядаємо як творче змагання 3 теоретичної та практичної підготовки здобувачів вищої освіти, спрямоване на активізацію їх пізнавальної діяльності. Вона $є$ елементом науково-дослідної роботи у ЗВО. 
На сьогодні кафедрами теоретичної механіки, інженерної графіки та машинознавства Національного університету водного господарства та природокористування (далі - НУВГП) і технологічної освіти Рівненського державного гуманітарного університету (далі - РДГУ) в означеному напрямі ведеться результативна робота, яка має методично правильний і систематизований характер. Це насамперед проявляється у визначенні тематики проведених регіональних олімпіад, розробці практико-орієнтованих завдань, підготовці учасників, організації та проведенні олімпіади, підбитті підсумків проведених заходів.

Прикладом може бути щорічна регіональна студентська олімпіада 3 геометричного моделювання на ПЕОМ серед здобувачів вищої освіти I-V курсів. Вона користується значним інтересом серед учасників і науково-педагогічних працівників 3ВО. У різні роки переможці та призери цієї регіональної олімпіади з успіхом брали участь у II етапі Всеукраїнської студентської олімпіади 3 геометричного моделювання. Так, Возняк Дмитро (НУВГП) посів I місце $(2013$ р.); Переходько Василь (РДГУ) - III місце (2013 р.); Лагодюк Павло (РДГУ) - I місце (2019 р.); Мельник Василь (НУВГП) - ІІІ місце (2019 р.).

Підготовка цікавих і творчих завдань, розробка критеріїв оцінювання результатів вимагає проведення значної організаційної роботи. Активне впрова- дження в освітній процес наших кафедр технологій 3D i 4D моделювання призвело до необхідності організації та проведення регіональної олімпіади, яка $\epsilon$ затребуваною і збирає велику кількість учасників. Насамперед вона орієнтована на здобувачів вищої освіти I-V курсів університетів та студентів коледжів, які ознайомлені 3 технологією 3D i 4D моделювання засобами комп'ютерної графіки.

14 березня 2019 року на базі кафедри технологічної освіти РДГУ відбулася X ювілейна регіональна студентська олімпіада, а в червні - предметна олімпіада з анімації на базі ІПО НУВГП. У заході з комп'ютерного моделювання взяли участь 34 здобувачі вищої освіти ЗВО м. Рівного, Рівненської та Волинської областей, а 3 анімації - 17 здобувачів вищої освіти спеціальності «автомобільний транспорт» НУВГП.

Структура конкурсних завдань передбачала застосування не лише теоретичних знань, а й практичних навичок здобувачів вищої освіти і студентів коледжів із геометричного моделювання засобами комп'ютерної графіки. Конкурсні завдання полягали в моделюванні тривимірної моделі деталі типу «Корпус» за робочим креслеником (див. рuс. 1) та анімації збірки (див. рис. 2). Збірка для анімації складається iз восьми однотипних деталей, а програмами для виконання завдань є такі, як AutoCAD, КОМПАC, Solid Works, Inventor та ін.

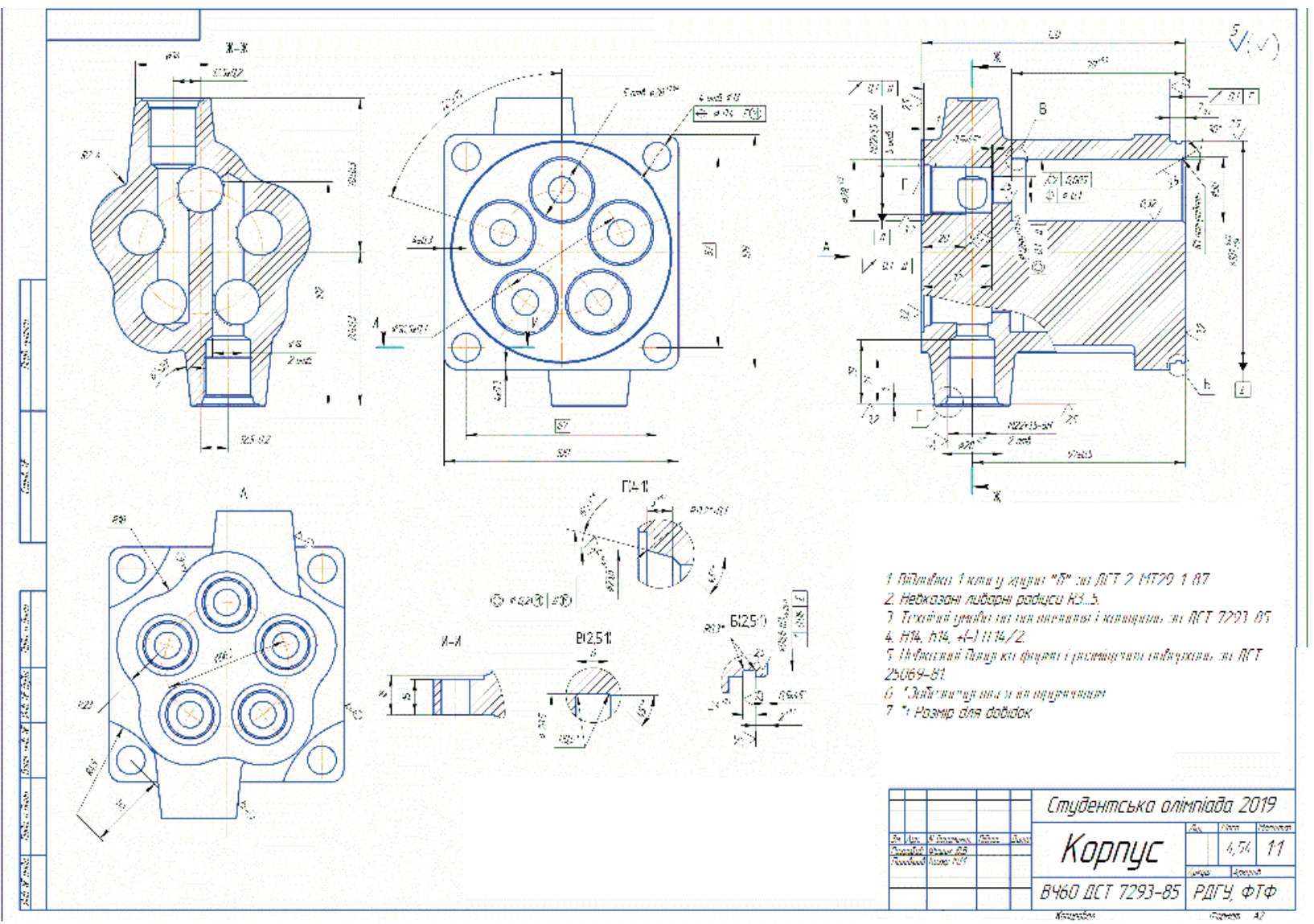

Рис. 1. Робоче креслення корпусу

При оцінці робіт основний ухил робиться на такі критерії: максимальна правильність розуміння («читання») кресленика $\mathrm{i}$, як наслідок - точність побудови 3D-моделі; вміння користуватися програмним продуктом; швидкість виконання завдання. На рисунках 3-4 наведено зразок виконання завдання з олімпіади.
Як засвідчує досвід, здобувачі вищої освіти та студенти коледжів, які брали участь у регіональних олімпіадах минулих років, свою професійну діяльність надалі так чи інакше пов'язують із технологіями CAD - проєктуванням у різних галузях народного господарювання. 

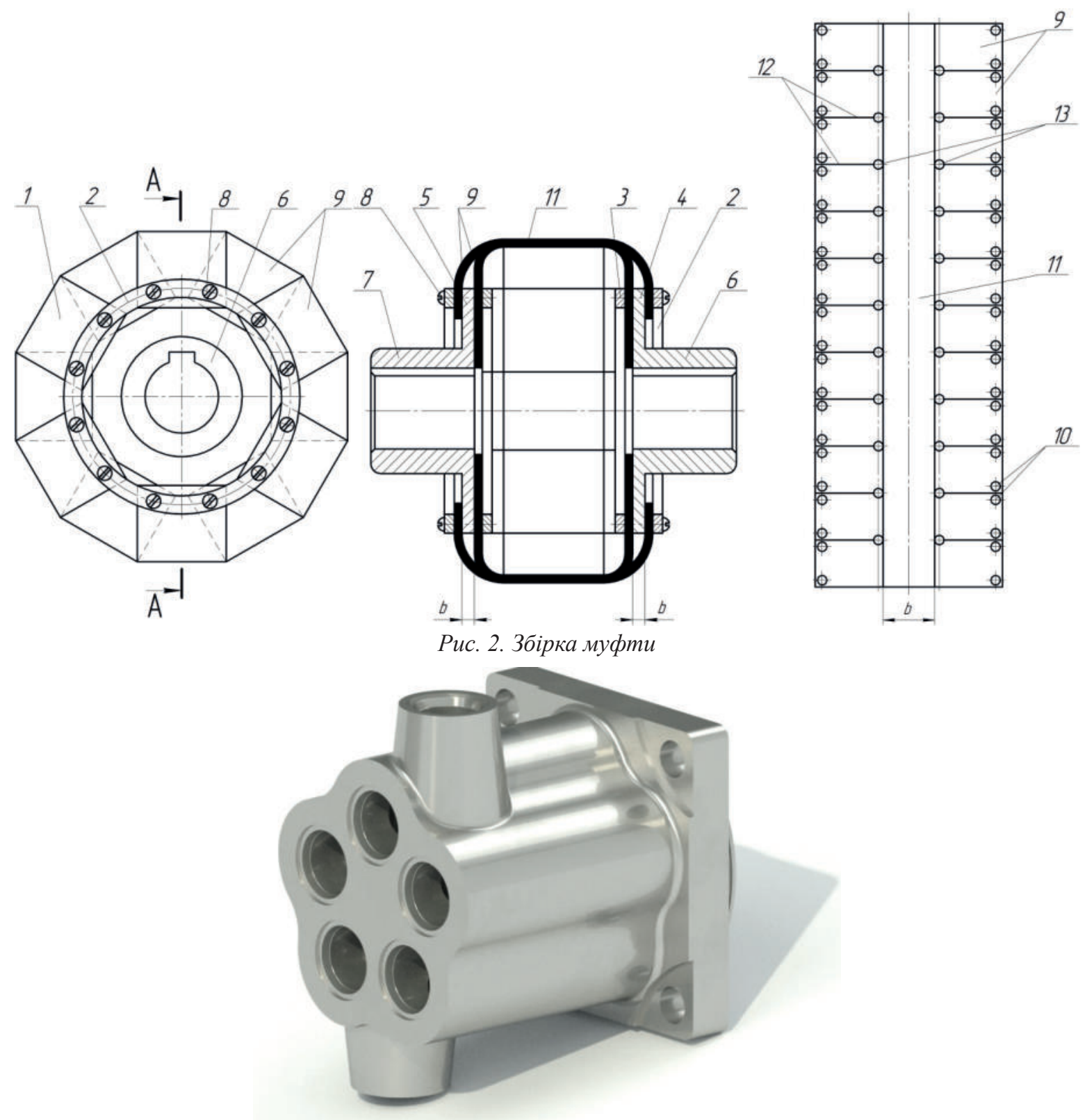

Рис. 3. Зразок виконання завдання олімпіади з тривимірного моделювання

Результатом такого підходу до освітнього процесу є коригування навчальних програм графічних дисциплін з урахуванням сучасних тенденцій у промисловості та виробництві. Так, упровадження у 2019 р. в освітній процес НУВГП засобів чотиривимірного моделювання (див. рис. 4) засвідчило необхідність доповнення програми регіональної олімпіади ще одним завданням - моделюванням складального кресленика засобами чотиривимірної графіки (анімація). Зокрема В. Бойко, С. Муратова та О. Попова вказують на важливість того, щоб здобувачі вищої освіти максимально активно брали участь у навчальній інноваційно-проектній діяльності з урахуванням постійно змінюваних завдань інженерного проєктування,

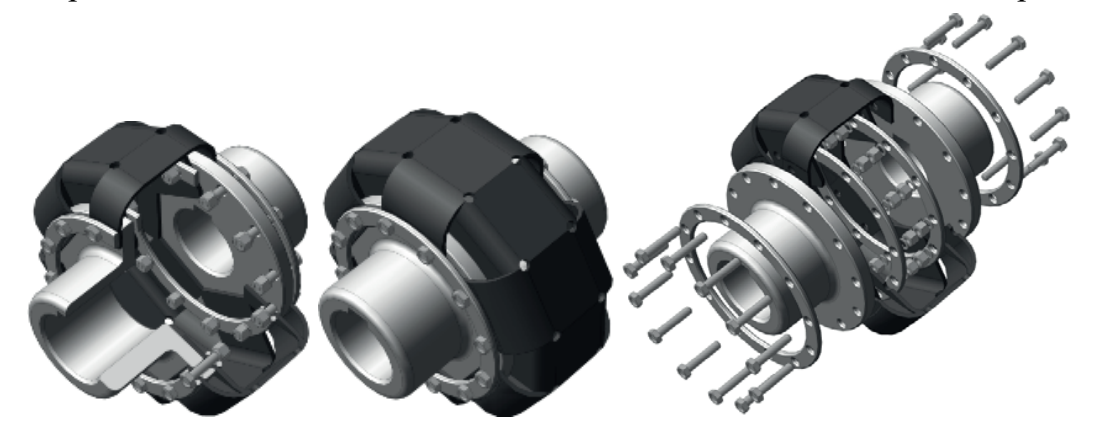

Рис. 4. Зразок виконання завдання олімпіади з анімаџії збірки 
а науково-педагогічні працівники - розширювали діапазон використання інформаційних технологій як засобу підтримки навчально-пізнавальної діяльності майбутніх фахівців у процесі проектування $[1 ; 4 ; 11]$. За такої організації навчального процесу суттєво активізується навчально-пізнавальна діяльність здобувачів вищої освіти та студентів коледжів, 3'являється можливість розвитку пізнавальної мотивації завдяки використанню колективних форм роботи та перетворенню навчання в самонавчання. Очевидною стає ефективність процесу навчання загалом та комп'ютерної графіки зокрема.

Готуючись до олімпіади, здобувачі вищої освіти НУВГП навчалися в гуртку моделювання під керівництвом науково-педагогічного працівника 3 використанням індивідуальної, групової та Белл-ланкастерської форм навчання. Остання передбачає поділ здобувачів на групи з приєднанням до них старшокурсників, так званих «моніторів». «Монітори» володіють кількома графічними пакетами і передають здобуті знання своїм молодшим колегам. Такий підхід дає можливість здобувачам вищої освіти самостійно оволодівати кількома графічними пакетами та підвищувати рівень графічної компетентності. Також нами було розроблено педагогічний програмний засіб «Системи САПР» [2], який сприяє кращому оволодінню графічними пакетами. При цьому важливим джерелом набуття знань стає інтерактивна взаємодія не тільки між науково-педагогічним працівником і здобувачем вищої освіти, а й між самими здобувачами.

Вивчення основних можливостей систем САПР, опанування технологією конструювання, проєктування в програмах останнього покоління (наприклад, SolidWorks i AutoCAD) дає змогу оволодіти революційними технологіями конструювання тривимірних моделей деталей i виробів із наступним, практично автоматичним, отриманням конструкторської документації. Поступове освоєння всього спектра можливостей систем САПР та виконання низки самостійних завдань формує високий рівень професійної підготовки фахівця. Така технологія організації навчання не лише сприяє забезпеченню глибини засвоєння навчального матеріалу, а й підвищує рівень інформаційної культури здобувачів вищої освіти, причому істотно змінюється їх роль: вони стають активними учасниками освітнього процесу, змінюється джерело мотивації навчання (особиста зацікавленість), підвищується рівень активності, творчості. Водночас зростає і роль науково-педагогічного працівника як лідера та організатора такого процесу. Слід зауважити, що проведення регіональних олімпіад значно збільшує інтерес здобувачів вищої освіти та студентів коледжів до всього комплексу графічних дисциплін і сприяє підвищенню ïx графічної компетентності. Поряд із цим створюються осередки «молодих конструкторів», які мають можливість започаткувати свою взаємодію через комп'ютерно-опосередковані комунікації.

Висновки. Отже, специфіка організації регіональної олімпіади 3 геометричного моделювання та предметної олімпіади 3 анімації збірок засвідчила неабияку ефективність. Вона є засобом виявлення i залучення обдарованих здобувачів вищої освіти та студентів коледжів до науково-дослідної роботи, починаючи з молодших курсів, та дає змогу встановити тісний контакт із виробництвом. Особливого значення при цьому набуває вивчення окремих дисциплін та використання різноманітних форм і методів навчання, у процесі якого здобувачі вищої освіти отримують грунтовне й різнобічне уявлення про досліджувані явища та процеси. Таким чином на майбутніх фахівців здійснюється мотиваційний вплив, як наслідок у них формується власна думка щодо тих чи інших проблем, розвивається наукове мислення. Натомість використання інформаційно-комунікаційних технологій під час підготовки до проведення регіональної олімпіади завдяки комп'ютерно-опосередкованим комунікаціям дає змогу перейти до дистанційної освіти.

Перспективи подальших розвідок в означеному напрямі спрямовуватимуться на дистанційне навчання, яке є діяльнісним, творчим процесом, що покликаний формувати самодостатню творчу особистість здобувача вищої освіти. Означене будемо намагатися реалізувати через ігрове моделювання віртуальне конструкторське бюро.

\section{СПИСОК ВИКОРИСТАНОЇ ЛІТЕРАТУРИ}

1. Бойко В. А. Методика навчання інженерної графіки майбутніх інженерів-механіків засобами комп'ютерного моделювання : дис. ... канд. пед. наук / В. А. Бойко. - К., 2019. - 317 с.

2. Козяр М. М. Створення та використання педагогічних програмних засобів із вивчення систем автоматизованого проектування майбутніми фахівцями технічної галузі / М. М. Козяр, О.В.Парфенюк // Інноваційна педагогіка : науковий журнал. - Одеса : Причорноморський науково-дослідний інститут економіки та інновацій, 2019. - Вип. 14. - Т. 1. C. $80-86$.

3. Мельник I. Науково-дослідна робота студентів як компонент освітнього середовища підготовки майбутнього спеціаліста / I. Мельник // Психолого-педагогічні проблеми сільської школи : наук. збірник. Умань, 2007. - Вип. 21. - С. 85-91.

4. Муратова Е. И. Подготовка специалистов машиностроительного профиля к инновационно-проектной деятельности в условиях высшей школы : дисс. ... канд. пед. наук : 13.00 .08 / Е. И. Муратова. Тамбов, 2002. - 247 с.

5. Науково-дослідна робота в закладах освіти : методичний посібник / укл. Ю. О. Туранов, В. І. Уруський. - Тернопіль : АСТОН, 2001. - 140 с.

6. Ожга М. М. Проблеми графічної підготовки майбутніх інженерів-педагогів у наукових дослідженнях / М. М. Ожга // Проблеми інженерно-педагогічної освіти : зб. наук. праць. - Харків : Українська інженерно-педагогічна академія (УІПА), 2012. Вип. 34-35. - 347 с.

7. Олимпиады по инженерно-графическим дисциплинам как средство реализации практико-ориентированного обучения / В. А. Лодня, О. В. Никитин. URL: http://www.ng.sibstrin.ru/brest_novosibirsk/2018/ doc/060_1.pdf (дата звернення: 22.01.2019).

8. Павленко Т. І. Роль науково-дослідної роботи в підготовці та професійному становленні техніка-електрика на електротехнічному відділенні Дніпродзержинського енергетичного технікуму. URL: http:// ru.osvita.ua/school/lessons_summary/education/45712/ (дата звернення: 23.01.2019).

9. Повідайчик О. С. Особливості дослідницької підготовки фахівців у вищих навчальних закладах. URL: https://dspace.uzhnu.edu.ua/jspui/bitstream/ lib/20883/1/Повідайчик_Київ_2 (дата звернення: 13.01.2019). 
10. Попиченко С. С. Про деякі аспекти забезпечення едукаційного середовища для розвитку особистості студента : посібник для вчителів і студентів / С. С. Попиченко, Н. В. Рогальська. - Умань : РВЦ «Софія», 2007. - С. 9-15.

11. Попова О. П. Розвиток творчого потенціалу майбутнього інженера в процесі професійної підготовки у вищому технічному навчальному закладі : автореф. дис. на здобуття наук. ступеня канд. пед. наук : спец. 13.00.04 / О. П. Попова. - Запоріжжя, 2006. $20 \mathrm{c}$.

УДК 37.091.12:510.2]:008 - 047.22

DOI: 10.37026/2520-6427-2020-101-1-90-93
12. Фещук Ю. В. Олімпіада з комп’ютерної графіки як засіб активізації пізнавальної діяльності студентів / Ю. В. Фещук // Трудова підготовка в закладах освіти. - 2011. - №7/8. - С. 47-49.

13. Чемоданова Т. В. Олимпиады и конкурсы по компьютерной графике как метод интенсификации процессов инженерно-геометрического мышления студентов технического вуза / Т. В. Чемоданова // Педагогическая информатика. - 2004. - № 4. - С. 74-78.

Дата надходження до редакиіï: 20.01.2020 р.

\section{ОЛеНа МАРЧЕНКО,}

кандидат педагогічних наук,

дочент кафедри природничо-математичної освіти

Рівненського ОІППО

\section{РЕГІОНАЛЬНИЙ НАУКОВО-МЕТОДИЧНИЙ ПРОСКТ «КУЛЬТУРНІ КОДИ МАТЕМАТИКИ» ЯК ІНСТРУМЕНТ РОЗВИТКУ ПОЛІКУЛЬТУРНОЇ КОМПЕТЕНТНОСТІ ПЕДАГОГІВ}

У статті аналізуються результати першого етапу впровадження регіонального науково-методичного проєкта «Культурні коди математики», спрямованого на формування й подальший розвиток полікультурноі компетентності вчителів математики. Висвітлюються його системні зв 'язки із провідними положеннями проєкта «Майбутнє освіти та вмінь. Освіта 2030» Організачії економічного співробітництва та розвитку, а також перспективні шляхи реалізації суспільного запиту на агентність та інноваиії в освіті.

Ключові слова: полікультурна компетентність, професійні компетентності педагога, агентність, міжкультурний діалог у проиесі вивчення математики, культурні ияінності в освіті.

В статье анализируются результаты первого этапа осуществления регионального научно-методического проекта «Культурные коды математики», направленного на формирование и дальнейшее развитие поликультурной компетентности учителей математики. Освешаются его системные связи с основными положениями проекта «Будущее образования и навыков. Образование 2030» Организации экономического сотрудничества и развития, а также перспективные пути реализачии общественного запроса на агентность и инновачии в образовании.
Ключевые слова: поликультурная компетентность, профессиональные компетентности педагога, агентность, межкультурный диалог в прочессе изучения математики, культурные ценности в образовании.

The results of the first stage of implementation of the regional scientific and methodological project «The Cultural Codes of Mathematics» are analyzed in the article. The project is aimed at forming and further development of multicultural competence of mathematics teachers. It revealed the systematical links with basic concepts of Organisation for Economic Co-operation and Development (OECD) project «THE FUTURE OF EDUCATION AND SKILLS. Education 2030».

The article explored perspective directions of public inquiry into agency and innovations in education. It is just the problems of educational agency and the formation in its context of multicultural competence of the subjects of the educational process that the project «The Cultural Codes of Mathematics» is devoted.

The Ukrainian mathematics curriculum explanatory note for 5-9 grades explains that mathematics teaching should make some contribution to the formation of key competences, including information and understanding the cases of manifestation of mathematical laws in the field of culture. According to this the project 